\title{
ROMANIAN HORSE NAMES
}

\begin{abstract}
The present study focuses on identifying and classifying the equine zoonyms used in recent years in Romania, with the purpose of identifying the language trend and, if possible, what stands behind the motivation of onymic units. In addition, a comparison with the results of another study undertaken by us will be made, more specifically, a paper dealing with horse names extracted from the first survey (The Horse) issued by The Museum of the Romanian Language in 1922. The current study aims to identify the changes this onomastic segment was subject to.
\end{abstract}

KEYWORDS: horse names, zoonyms, the process of naming.

INTRODUCTION

The present paper looks into zoonymy, with a focus on Romanian equine stock in 2019, when the data was collected. In our analysis, we identified certain zoonym patterns following their etymology and semantics in order to illustrate the linguistic trends of the time. In order to address this issue, we consulted several websites and forums that provide horse-related information and advice for animal owners.

It is worth mentioning that the study is not our first investigation into this particular area of interest, since we published a similar one (Pușcaş 2019) about Romanian horse names which were fashionable around 1922, when the Museum of the Romanian Language conducted a survey about horse-related language ${ }^{1}$ (Chestionar pentru un atlas lingvistic al limbii române. I. Calul, Cluj, Institutul de Arte Grafice Ardealul). We will, therefore, also present a contrasting analysis with the aim of pointing out the transformations that occurred within zoonymy, which is often motivated by extralinguistic factors.

1 There were eight surveys conducted by the Museum in Cluj-Napoca in order to encourage village intellectuals (teachers, priests) to provide regional vocabulary and pronunciation regarding certain aspects of rural life (I. The Horse, 1922; II. The House, 1926; III. The Thread, 1929; IV. Names of Places and Names of Persons, 1930; V. The Sheepfold, Grazing and Milk Preparation, 1931; VI. Beekeeping, 1933; VII. Musical Instruments, 1935; VIII. Food and Beverages, 1937). 


\section{A THEORETICAL OVERVIEW ON ZOONYMS}

Zoonyms are defined as an onomastic subclass that refers to animals, more precisely to given proper names and to nouns denoting breeds and species. The present paper deals only with the specificity of the first category. Similarly to anthroponyms, zoonyms help to individualize, identify (more obvious in the case of animals), name and address animals (Bran 2011: 597). Creating a zoonym represents "a genuine act of speech, whose performative nature is manifest in the onomatologist's intention of implementing a change at the linguistic level by giving a name to an extralinguistic reality" (Felecan 2014: 269). The naming act implies "a self-reflexive verbal act" through "a classifying index" (the chosen name places the selected entity in a class) and through free creation (Felecan 2014: 280).

Zoonyms may be generated through the transition of appellatives or proper names to the onomastic sphere of zoonyms. Through this adoption of appellatives, the initial semantic motivation is partially maintained: zoonyms do not only "designate and interpolate, but they also refer to the semantics of the words they originate from. The connexion between the proper name and the base word is not completely blurred and the speaker still makes the semantic association between the two" (Bran 2011: 601). Furthermore, the labelling of an animal through anthroponyms suggests the predilection for "anthropocentrism" (Bran 2011: 597). This results in "approaching and humanizing" the animal (Zafiu 2006) by conferring it not only human traits, but also "the role of a family member" (Andreica 2011: 585).

The naming process is influenced by factors such as the owner's education, the type of environment he lives in and the ethnical group he belongs to, the animal's peculiarities or the owner's emotional attachment (Andreica 2011: 586). A few naming practices stand out as follows: "The name should be easily remembered and easily understood. The easier it is to pronounce and understand it, the better. Never use a confusing name, such as a name that sounds like an order" (A); horse names should be "strong, short and easy to pronounce" (E). It is also believed that "the name of a horse reflects its personality, its genetic inheritance and the owner's personal taste" (F); "if a horse is of noble origin, it takes its parents' name, especially if they have a title or pedigree" (D); "horse names may seem extravagant, especially when the owner intends to show the noble birth of the animal" (A). Horses are believed to accept their name easily (A) and certain changes in the naming pattern, as "people have decided to choose distinct names comparatively to what they used to" (B), including unisex names (A).

\section{CLASSIFICATION OF HORSE NAMES}

Proper names derived from common nouns or adjectives (onymization): "Words no longer belong to (...) the lexicon, but to the onomasticon (...). Subsequently, there is perfect formal identity between the appellative, or the adjective commonly used by speakers and the proper name, but with an obvious functional difference" (Bran 2011: 599). 
Appellatives may refer to coat colour (most names originate from adjectives describing colour that perform the purpose of nouns). Few such Romanian words have been identified: Alba 'white', Suru 'grey' and the unrelated equine colours Azur 'azure', Turcoaz 'greemish-blue', Albastrro <albastru 'blue', with an Italian phonetic mark. In addition, there are several names of Spanish (Blanca, El Blanco 'white', Tenebrosa 'dark') or English origin (Black, Blondie, Brown, Dark, Golden, Grey, Red, Scarlet, White). The name may be a compound containing an anthroponym or indicating a marital status (Billy Grey, Dark Lady) or a charactonym (Black Beauty). Sometimes, the name might indirectly reference the chromatic ${ }^{2}$ sphere: for instance, the Romanian acuarela 'watercolour' which comes with an unusual spelling (Acuarella) or the English Blush and Paint. In 1922, coat colour names outnumbered all the other names coming from other spheres; some of them came from common Romanian adjectives: Alba, Albu 'white', Galbin, Galbina ${ }^{3}$ <galben 'yellow', Negru, Neagră 'black', Roșu, Roșa 'red', Suru, Sura 'grey'; others were coined from semantic information [reference to the colour of (animal) hair/fur]: Murgu, Murga '(about a horse) dark-bay', Roibu, Roaiba '(about a horse) chestnut'. Some adjectives were of foreign origin: Dereș, Dereșa $<$ Hung. deres '(about a horse) greyish', Piroș, Piroșca $<$ Hung. piros 'red', Schimmel Germ. 'a grey or white horse'. However, very few names illustrating colour continue to be used in the light of tradition. Foreign influence is still strong nowadays, with English being the main language that spills into equestrian name creation in Romania.

Appellatives referencing distinctive markings seems to be less common nowadays, with scarce examples such as Dunguța Rom. 'little stripe', Dot (also a hypocoristic form of Dorothy). Other noteworthy zoonyms include Blue Eyes, Ciuffo It. 'tuft', Pistrui Rom. 'freckles' (a unique identifier of human beings). The 1922 survey yielded results which illustrate more richness of onymic units: Breazu, Breaza Rom. 'a horse with a white patch on the forehead or with a white stripe on the muzzle', Csillag Hung. 'star', Pintenogu, Pintenoaga Rom. 'a horse with white patches above the hooves or with white legs'.

Names also mirror size, as illustrated by the following examples: the Romanian words Micu, Mica 'little', Mititelu 'little', Voinicu, Voinica 'stout' were used in 1922. Their onymic counterparts of present interest exhibit the same specificity: Big, Forzuto It. 'big and strong', Magnus Lat. 'great', Micuțu Rom. 'little', Piccola It. 'little'.

Age and sex are visibly represented in the continuous use of the units Baby, Dama Rom. 'lady', Puiu Rom. 'whelp'. In recent times, other words have undergone the process of proprialisation, whether they come from Romanian (Junior, Prunc 'infant', Soramea-dragă 'my dear sister'), English (Itsi, Kid, Lady, Milady), French (Neveu 'nephew') or Spanish ones (Chico 'boy'). However, in 1922, proper names (for horses) came from Romanian appellatives such as Baba 'old lady', Băiatu 'boy', Fata 'girl', Fetița 'little girl', Piciu 'kid', and Puica, Puicuța 'pullet'.

In the current onomasticon, there are units referring to beauty that come from Romanian (Fermecător 'charming', Frumusețe 'beauty', Irezistibil 'irresistible', Prăfuit 'dusty' - an indirect reference to colour or lack of cleanliness, Superba 'superb' and

\footnotetext{
2 Many names that express colour have been placed into other categories to which they are also linked.

3 Some of the names employed in 1922 were used in dialectal or substandard forms, since respondents were encouraged to provide regional words and pronunciation, as the aim of the survey was to obtain a broad spectrum of authentic language.
} 
the syntagm Fată frumoasă 'beautiful girl'), English (Beauty, Hot, Majestic, Nice), Italian (Bellissimo 'gorgeous', Incanto 'delight', Maestoso 'majestic'), French (Belle 'beautiful', Jolie 'pretty') or Spanish (Celeste 'celestial', Guapo 'beautiful', Hermoso, Hermosa 'beautiful', Simpático 'nice'). A century ago, several Hungarian words were preferred instead: Cinoș < csinos 'nice', Pumpaș <pompás 'attractive', Sep <szép 'beautiful', together with the names of Romanian origin such as Fain 'beautiful', Mândra 'handsome'.

Temperament traits - be they positive or negative - are also represented in the creation of horse appellatives. Positive ones express bravery, velocity or energy (Brave, Convingătoare Rom. 'persuasive', Curajos Rom. 'brave', Furtunos Rom. 'tempestuous', Goldwing, Înflăcărat Rom. 'ardent', Master, Neînfricatul Rom. 'fearless', Rapid Rom. 'fast', Sassy, Spirit nesăbuit Rom. 'reckless spirit', Sprintenu Rom. 'agile', Ultrasonic, Valoroso It. 'brave', Vigilante It. 'alert', Well). Intelligence (Smart), mildness and charm (Divine, Galant Rom. 'courteous', Graziosa It. 'gentle', Kind, Magic, Nobil Rom. 'noble', Pios Rom. 'pious', Quieta Sp. 'still') also make the cut when it comes to creating horse names. Additionally, names expressing mood (Felicitá It. 'happiness', Funny, Gioia It. 'joy', Happiness, Smile, Spirit), loyalty (Credincios Rom. 'loyal', Loial Rom. 'loyal'), success (Lucky, Norocos Rom. 'lucky'), ambition (Ambiție Rom. 'ambition', Fervoare Rom. 'fervour', Provocator Rom. 'provoking') and singularity (Maxima Rom. 'maximum', Ultras, Unica Rom. 'unique', Vitale It. 'vital') also made our roster of appellatives. In the survey conducted by the Museum, the names they identified suggested bravery (Bator $<$ Hung. bátor 'brave', Liberă Rom. 'free', Viteaz Rom. 'brave'), intelligence (Istețu, Isteața Rom. 'smart'), mildness (Blândă Rom. 'mild', Lina Rom. 'slow', Nobil Rom. 'noble') or mood (Vidam <Hung. vidám 'joyful'). When it comes to names expressing negative traits, they typically imply lack of control (Derbedeu Rom. 'tramp', Diabolic Rom. 'diabolical', Furia Rom. / Ira Sp. 'fury', Libera Rom. 'free', Monella It. 'naughty', Nărăvașa Rom. 'randy', Vagabondo/a Sp. 'vagabond', Selvaggio It. 'wild', Wild), indolence (Floppy, Lax Rom. 'loose', Slowly, Último Sp. 'the last one') and solitude (Solitario Sp. 'solitaire'). Overall, the $20^{\text {th }}$ century onymic choices are connected to the same spheres, although they are less diverse: lack of control (Buidoș < Hung. bujdosó 'wandering', Cruntu Rom. 'cruel', Dura Rom. 'tough') or indolence (Moloman Rom. 'lazy, stupid').

Appellatives designating animals carry analogies built on certain resemblances between the two animals (e.g., temperament and colour) (Pașca 1936: 154). This type of appellatives drew from a larger pool of domestic animals one hundred years ago when Romanian zoonyms such as Bibilică 'guinea-hen', Cocoș 'rooster', Pircă 'guinea-hen', Rățoiu 'drake' were very common. Alternatively, the 2019 corpus registers only one onymic unit, namely Duck. As far as names originating in wild animals are concerned, there is a predilection for mammals - the animals with a constant presence in the equine onomasticon being the bear (Rom. Ursu), the fox (Fox, Germ. Fuchs, Rom. Hulpea 'vulpea', Roca $<$ Hung. róka - in 1922, Sp. Zorra), the wolf (Rom. Lupu, Farcaș $<$ Hung. farkas - in 1922, Wolf), the lion (Rom. Leu - in 1922, Lion, Sp. Leona 'lioness'). A century ago, the zoonyms Cerb Rom. 'stag', Iepuraș Rom. 'little rabbit', Tigru Rom. 'tiger', Vidra Rom. 'otter', Zebra were also used, while the specificity of the current onomasticon arises from the units Koala, Pingu $<$ Rom. Pinguin 'penguin', Toro Sp. 
'bull' and from the employment of a word designating animal limbs: Zampetta It. 'paw'. Furthermore, a century ago, a common practice in the act of naming horses was the use of ornitonyms, hyperonyms being frequently onomysed through the diminutives Madar < Hung. madár 'bird', Păsărel, Păsărica Rom. 'little bird'. Bird species were also popular: Cioara Rom. 'crow', Сucu Rom. 'cuckoo', Fecske Hung. 'swallow', Mierlă Rom. 'blackbird', Rândunica Rom. 'swallow', Rigo <Hung. rigó 'blackbird', Şoimu Rom. 'falcon'. The bird species performing the onymic function nowadays are Corbu Rom. 'raven' (also in 1922, together with its Hungarian pair Hollo and indirectly motivated by colour association), Eagle (also in 1922, but in Romanian, Vultur), Flamingo, Paloma Sp. 'dove' (also in 1922, in Romanian: Porumb, Porumba, Porumbița are colour based), Pellicano It. 'pelican', Raven. Other prolific zoonymic vocabulary relates to insects (in 1922, Fluturaş Rom. 'little butterfly', Gândac Rom. 'bug'), arachnids (Spider) and aquatic animals (Coral, Ricciola It. 'amberjack' and in 1922, Hering Rom. 'herring').

Appellatives designating plants (phitonyms) suggest "common aspects between the plant and the horse regarding the colour or the structure" (Pop 1929: 107). In 1922, the hyperonym /flower/ was used in Italian (Fiora), Romanian (Floarea) and Hungarian (Virag <'virág'), while nowadays the French Fleur is employed. Other general nouns that became proper ones designate flower species: Daisy (also in 1922 in the form Margareta Rom.), Iris (also in 1922), Jasmine, Lilla It. 'lilly', Lilly, Rose (also in 1922, in parallel forms: Roza Rom., Trandafir Rom.). Some phitonyms were used exclusively in 1922 as follows: Bujor Rom. 'peony', Cila $<$ Hung. csilla 'violet'. Trees (Oliv Rom. 'olive tree', in 1922, Olmo Sp. 'elm tree', Palma Sp. 'palm tree', Salcie Rom. 'willow tree', Stejar Rom. 'oak tree', in 1922, Willow), aromatic plants (Busuioc Rom. 'basil', Leuștean Rom. 'lovage', both in 1922, Dafin Rom. 'laurel', Peppermint), fruits (Căpșună Rom. 'strawberry', Limone It. 'lemon', Mura Rom. 'blackberry', in 1922, Peach, Zabon) or miscellaneous plants (Abanos Rom. 'ebony tree', Clover, Ivy, Lupin, Macchia, Mandrake, Mărăcini Rom. 'bramble') were also employed.

Appellatives designating titles or social roles carry cultural information about the Turkish (Emir, Paşa Rom. 'pasha', Sultan - also in 1922), Indian (Maharajah, Rajah) and Russian worlds (Czarina, T,ar Rom. 'czar'), about Western Europe (Hidalgo Sp. 'nobleman', Marchiz Rom. 'marquis' - also in 1922), or without a specific mark (Crai Rom. 'emperor', Ducesă Rom. 'duchess', Imperatorius Lat. 'belonging to a general; imperial', Impărat Rom. 'king', Majesty, Prince, Princess, Principe Rom. 'prince', Queen, Regină Rom. 'queen', Reina Sp. 'queen').

With respect to zoonyms derived from appellatives designating villains, Betyar $<$ Hung. betyár 'outlaw' was quite trendy in 1922, while from the $21^{\text {st }}$ century onymic units such as Apache Sp. 'a violent street ruffian', Baddy, Bandit, Bandido Sp. 'bandit', Pirata Sp. 'pirate' stand out. In addition, in 1922, there were proper names related to pastoral or military life (Baciu Rom. 'shepherd', Boitar $<$ Hung. bojtár 'little shepherd', Cioban Rom. 'shepherd', Husar 'hussar', Vezer <Hung. vezér 'commendar'), while the ones from 2019 that originate from appellatives designating jobs are more heterogeneous; they derive from lexical units connoting wilderness and movement (Balerina Rom. 'ballerina', Cowboy, Golden Dancer, Hunter, Wind Dancer), they relate to armed forces (Colonnello It. 'colonel', Ninja, Sergent Major Rom. 'sergeant major') or seem to 
have no manifest motivation (Cooper, Diva, DJ Maestro, Jurist, Oracol Rom. 'oracle', Vocalist). Other onymic units are tied to the idea of exploration (Călător Rom. 'traveller', Cercetaş Rom. 'scout', Pilgrim, Voyager), they involve exaltation (Amigos Sp. 'friends', Curtezan Rom. 'suitor', Ídolo Sp. 'idol') or they do not seem to indicate an obvious association (Alias, Alibi, Hippie, Vrăjitoare Rom. 'witch'). Another category that we would like to point out is the one of appellatives designating fantastic characters. Whereas the 1922 zoonyms came from appellatives belonging to fairy tales (Tündér Hung. 'fairy', Zmeu Rom. 'dragon'), in 2019, the majority of them are religious in nature (Angel, Fantoma Rom. 'ghost', Ghost, Inger Rom. 'angel', Diablo Sp. 'devil', Sheitan Ar. 'devil' - also the name of a movie).

Zoonyms relying on appellatives that designate natural phenomena, natural structures or nature have kept up their popularity through time reference - with some of them indicating velocity: Air, Blast, Blaze, Brina It. 'frost', Fiamma It. 'flame', Fiocco It. 'fire', Flame, Flash, Foc Rom. 'fire', Fuego Sp. 'fire', Fulger Rom. 'lightning', Fulmine It. 'lightning' (with the 1922 parallel version Vilam <Hung. villám), Furtună Rom. 'storm' (in 1922, Vihar Hung.), Glacial Storm, Goccia It. 'drop', Mistral, Morgana, Nebbia It. 'fog', Oasis, Pioggia It. 'rain', Rain, Rugiada It. 'dew', Scintilla It. 'spark', Tempesta It. 'storm', Temporale It. 'storm', Terremoto Sp. 'earthquake', Thunder, Tsunami, Tuono It. 'thunder', Tunet Rom. 'thunder', Uragan Rom. 'hurricane', Vento It. 'wind' (in 1922 the corresponding words were the Romanian Vântu or the Hungarian Szellö 'breath of wind'), Volcano, Wind. Other onymic units may be partially explained by the colour resemblance between the animal and the initial denotatum of the appellatives: Cloud, Ice, Moonlight, Nieves Sp. 'snow', Nuvola It. 'cloud', Ray, Stardust, Starlight, Tenebrosa Sp. 'gloomy', Wood, Zăpadă Rom. 'snow', or seem to have no clear origin: Forrest, Océano Sp. 'ocean', Rainbow, Río Sp. 'river', River, Sky.

There are also proper names imported from the field of geographical orientation (North, West), or they suggest moments of the day (probably in connection with equine colour: Amurg Rom. 'dusk', Midnight, Night, Notte It. 'night', Zaira It. 'dawning'). Additionally, some of them are suggestive of seasons (Primavera Sp. 'spring', Summer, Toamnă Rom. 'autumn', Autumn Glory, Winter), metals, materials or substances (Ambra Rom. 'amber', Cărbune Rom. 'coal', Cobalt, Iron, Moonrock, Wax), weapons (suggesting velocity: Freccia It. 'arrow', Glonț Rom. 'bullet', Săgeată Rom. 'arrow', Saetta It. 'arrow', Spike, Trăgaci Rom. 'trigger'). Entertainment also seems to be a rich source of appellatives (Boomerang, Hockey, Joker, Laser Game, Păpușică Rom. 'little doll', also a word of endearment, Singo, Tag-ul Rom. 'the tag', Trottola It. 'spinner', Zar Rom. 'dice', Zendo, Zoom, the syntagm King of Diamonds - from playing cards), just like ornaments or ostentation were (in 1922, Barşon Rom. 'velvet', Cercel, Cerceluşa Rom. 'earring', Ciucurel Rom. 'little tassel', Rubin Rom. 'ruby'. In 2019, precious stones or minerals are much trendier sources of horse names - Ametist Rom. 'amethyst', Crystal, Cristal Rom. 'crystal', Granite, Jad Rom. 'jade', Onix Rom. 'onyx', Opal, Perla Rom. 'pearl', Cuarzo Sp. 'quartz', Rubin Rom. 'ruby', Safir, Safira Rom. 'saphire', Zaffiro It. 'saphire', Zircon, metals - Argento It. 'silver', Silver, Zinc, money - Dollar, jewellery - Jewel, bones - Fildeș Rom. 'ivory', fabric - Velvet or abstract words - Lux Rom. 'luxury'). In current times, drinks (often motivated by colour resemblance: Cafea Rom. 'coffee', Coke, Coniac Rom. 'brandy', Mocca Rom. 'mocha', 
Mojito, Nectar, Spritz, Xante), and food (spices: Chilly, Espezia It. 'spice', Ginger, Harisa, Piper Rom. 'pepper', Scorțişoară Rom. 'cinnamon', Vanilla, Zafferano It. 'saffron', Zenzero It. 'ginger'; sweets: Candy, Chocolate, Ciocolată Rom. 'chocolate', Chantilly Fr. 'cream', Creamy, Fursec Rom. 'cookie', Honey, Loly (<lollypop), Miele It. 'honey', Muffin, Sugar; but also Butter, Oden, Omelette, Tapioca, and Zama Rom. 'soup') also gave us a wealth of fascinating new names for horses.

The 1922 onomasticon also relied on abstract nouns to generate zoonyms (Gându Rom. 'thought', an indication of velocity, Mila Rom. 'mercy') and, a century later, the category of virtues or positive situations is manifest in creating new zoonyms as follows: Cabala Rom. 'cabal', Desiderio It. 'wish', Euforia Rom. 'euphoria', Habbit, Harmony, Hope, Karma, Liberty, Love, Peace, Serenity, Speranță Rom. 'hope'. Other zoonyms express the idea of winning a competition: Abis Rom. 'abyss', Attitude, Autumn Glory, Brio Rom. 'to win with flying colours', Dreams, Evento Sp. 'event', Fame, Fantasy, Illusion, Impatto It. 'impact', Impeto It. 'impetus', Legendă Rom. 'legend', Magic Dream, Memory, Ombra It. 'shadow', Passion, Quality, Shadow, Umbră Rom. 'shadow', Utopia, Vanity, Vita It. 'life'. Although they seem to have a negative meaning, some onymic units may indicate a positive racing experience for the horse owner: Calamitate Rom. 'calamity', Coșmar Rom. 'nightmare', Revenge, Spulber Rom. 'dissipation', Urlo It. 'scream', Veleno It. 'venomous', Vendetta It. 'revenge'. Alternatively, other zoonyms do not carry a positive or a negative connotation such as: Enigma, Essenza It. 'essence', Nadir, Nouvelle Fr. 'news', Whisper.

Furthermore, there are onymic units that suggest the owner's feelings towards the animal': in 1922, Kedveș <Hung. kedves 'cute, dear' was quite common, while the 2019 corresponding zoonyms were of German (Liebe 'dear, love'), English (Love), Romanian (Favorit 'favourite'), Italian (Cuore 'heart', Dolcezza 'sweetness') or Turkish origin (Așk'love').

Some proper names were not included in any appellative group: Arena, Avion Rom. 'plane', Baston Rom. 'walking stick', Bobină Rom. 'reel', Bollicina It. 'bubble', Bolt, Bulgăraş Rom. 'little lump', Crono, Elisir It. 'elixir', Favola It. 'fable', Fax, Grease, Melody, Quena 'the traditional flute of the Andes', Uniform, Union, Urbano/Urbana Sp. 'urban', Zuffolo 'an Italian flute'. The onymic function is also performed by interjections and greetings (Hello, Tete, Yuppy), verbs (in 2019, some of them were English - Fly, Impress, Jumping, Look, Remember, or Italian - Andiamo 'Let's go'). Numbers (One), prepositions (Over, Under), abbreviations ( Ufo), and complex structures (Nu-te-voi-uitaniciodată Rom. 'I will never forget you', One day, Până-când-moartea-ne-va-despărți Rom. 'till death do us part') also seemed to play the same function.

Proper names derived from other proper names (transonymization) included, first of all, anthroponyms. This rich layer contains Romanian given names, with certain onymic units keeping their popularity still as follows: Diana, Maria, Marta, Mircea, Olga, Stela (zoonyms can be also related to colour, denoting, for example, a horse with a white patch on its forehead), Victor, Victoria. Whereas the masculine anthroponyms employed pre-eminently nowadays are Aron, Dan, Felix, Gabriel, Luca, Marcel, Ovidiu, Paul, Robert, Sebastian, Silvan, Simeon, the ones which appear

\footnotetext{
4 Some of the zoonyms listed next to the properties of beauty, age or size also belong to this category.
} 
exclusively on the 1922 list include Marcu, Sever, Toma, and Vasile. In 1922, feminine names such as Aurora, Didina, Eleonora, Flora, Iulia, Lia, Nina, and Vasilica were popular, while the $21^{\text {st }}$ century gave us a larger variety in this respect as follows: Adela, Adina, Antonia, Carina, Codruța, Cora, Crina, Dana, Denisa, Dianora, Doina, Elisa, Elvira, Eva, Gloria, Irina, Lavinia, Letiția, Liana, Marcela, Octavia, Olimpia, Olivia, Ortensia, Paula, Rebeca, Roxana, Sabrina, Sara, Teodora, Vera, Veronica, Victoria, Violeta, Viviana, and Zoe.

Other anthroponyms are of foreign origin - for instance, Hungarian (extremely fashionable one century ago: Árpád, Bela, Boglár, Géza, Ghiurca, Hajnal, Ida, Istvan, Marghit, Micloș, Vilma, Șandor, Zoltán; in the present, Atilla, Martin, Noémi, and Orsolya), German (the constant names Frida, Linda, Lola, Oscar, and nowadays, Albert, Bruno, Getrude, Karl, Leonard, Louisa, Vanda, Walt, and Wilda). Other anthroponyms were English in origin (feminine: Adison, Agatha, Alice, Brenda, Brianna, Camilla, Caroline, Catrine, Chloe, Daisy, Dorothea, Elizabeth, Emily, Hannah, Heather, Hellen, Hilary, Janet, Jennifer, Josephine, Julie, Lucy, Mary, Megan, Ophelia, Pamela, Phoebe, Priscilla, Rachel, Rose, Rosemary, Sharon, Sophie, Tamira, Tiffany, Tracy, and Vanessa; masculine: Alexander, Allan, Ambrose, Arthur, Ben, Brandon, Cecil, Charles, Duncan, Kay, Kevin, Jason, Jeremy, Joe, Jonathan, Mark, Nigel, Oliver, Randolph, Roger, Silvester, Whitney, Yonas, and Zack), Irish (Cedric, Conan, Fiona, Tara), Spanish (feminine: Alma, Belén, Dolores, Esmeralda, Gala, Isabel, Liria, Noelia, Pedra, Penélope, Pilar, Ramira, Rosaura, Samanta, Vera Luz, Xaviera, Ximena, Xoana; masculine: Alonso, Alfonso, Armando, Felipe, Fernando, Jaime, Lucas, Luis, Julio, Pedro, Ramiro, Ruben, Ubaldo, Xavier), French (Anais, Avril, Béatrice, Brigitte, Camille, Charlene, Eloise, Etienne, Giselle, Hugo, Jacqueline, Joelle, Michelle), Italian (Annabella, Arabella, Cesare, Fabia, Filippo, Isabella, Loretta, Marco, Marisa, Orietta, Orlando, Rosabella, Tobia, Ulrico, Umberto, Valentino, Vicenzo, Violante), Turkish (Oman, Omet, Osman, Otman - all in 1922, Alatan, Hurrem, Mustafa), Greek (Yani - in 1922, Aris, Leonida), Basque (Zukia), Slavic (Petear <Serb. Petar, Ruzia both in 1922, Dominika, Drago, Igor, Iuba, Iuri, Ivan, Nikita, Oxana, Raina, Ustinya, Vania, Waclawa, Yelena), Hebrew (Aram, Yafa, Yakira, Yardena, Yarona, Zakiah), Latin (Beatrix, Quintus), Arabic (Anis, Jalal, Karima, Leilah, Nedjary, Nigar, Wafiya, Widad, Yadira, Zubaida), Indian (Nanda, Zareen), and Japanese (Ayako).

The Romanian hypocorism or diminutive stock included, in 1922, feminine names such as Dora $<$ Teodora, Fani $<$ Ștefana (also in 2019), Flori, Floriţa $<$ Floare, Leanca $<$ Elena, Linca $<$ Ilinca, Lora $<$ Flora, Marița $<$ Maria, Neli $<$ Cornelia, and Steluca, Steluța $<$ Stela, while in 2019 the fashionable names were Angy $<$ Angela, Anita, Anuca $<$ Ana, Bibi $<$ Bianca, Dea $<$ Andreea, Ema $<$ Emanuela, Flo $<$ Florina, Kari $<$ Carina, Lena $<$ Elena, Mia, Mimi $<$ Maria, Roxi $<$ Roxana, and Tea $<$ Teodora. The 1922 popular masculine names were Dani <Daniel, Doru <Teodor, Fănel $<$ Ștefan, Ghiță, Gicăa, Gogu $<$ Gheorghe, Mișu, Mițu <Mihai, Nicu <Nicolae, while in 2019, Dinu <Constantin, Geo $<$ George, Sebini (probably an italianizing version of Sebastian), Teo <Teodor, Toni $<$ Antoniu.

The hypocorisms and diminutives of foreign origin derive from Hungarian (a rich category in the $20^{\text {th }}$ century such as: Bandi $<$ András, Barna $<$ Barnabás, Feri $<$ Ferenc, Ghiuri < Gyuri < György, Ioșca <Jóska <József, Jancsi <János, Lori <Lóri <Lóránt, 
Marișca $<$ Mariska $<$ Mária, Pișta $<$ Pisti $<$ István, and Șari $<$ Sári $<$ Sára ; there are also constant onymic units: Laci <László, Lilu <Lilla $<$ Karolina, Júlia, Liliána), Slavic (a plentiful category a century ago: Aleșa <Александра, Colea <Николай, Мaşa $<$ Мария, Nataşca <Наталия, Sonea <Софья, Vani, Vanica <Иван, while in 2019: Misha, Sasha < Михаиил, Tania < Татьяна, Tasha <Наталия), German (in 1922: Franț $<$ Frantz $<$ Franziskus, Friț, Friți $<$ Fritz $<$ Friedrich, Hanț, Hanzi/Hanți <Johannes, Ilda $<$ Hilda, Luizi, Lisi, Lizi <Luisa; nowadays: Franzi, Ilda, Kurt <Konrad), Jewish (in 1922, Ițic, Ițig <Isaac, Săli <Salah), English (Abby < Abigail, Betty/Elly/Lisa/Lizzy/Missy $<$ Elizabeth, Bill $<$ William, Charlie $<$ Charles, Cindy $<$ Cynthia, Dolly, Dorothy $<$ Dorothea, Jake <Jacob, Jenny <Jennifer, Jonny <John, Jordy <George, Josy <Josephine, Kori $<$ Corey, Lana $<$ Alana, Lea $<$ Leah, Mandy $<$ Amanda, Maggie $<$ Margaret, Milly $<$ Emily, Molly <Mary, Nancy <Anne, Nicol <Nicholas, Patty <Patricia, Penny <Penelope, Rick $<$ Richard, Sandy $<$ Alexander, Teddy $<$ Theodore, Terry $<$ Terence, Wendy/Winnie $<$ Gwendolyn), Italian (Bella $<$ Isabella, Leo $<$ Leonard), Spanish (Conchita $<$ Concha $<$ Concepción, Evita $<$ Eva, Katy $<$ Catherine, Lola, Lolita $<$ Dolores, Norita $<$ Nora, Pablito $<$ Pablo, Paco $<$ Francisco, Pepe $<$ José, Pepita $<$ Pepa $<$ Josefa, Rafa $<$ Rafael, Rosita $<$ Rosa).

The most common surnames employed in 1922 were Ilca, Mașca, Riga, Vándor, Vida, Vidran. In the $21^{\text {st }}$ century, few surnames of Romanian origin are used (Chira), while onymic units of English (Beckett, Eaton, Hale, Jackson, Jefferson, Lewis, Nilson, Russell, Thomson, Watson), Irish (O’Hara, O'Neill), French (Piccard), Italian (Ercolina) or Spanish origin (Abalo, Salazar, Zuela) are more popular.

Some names of celebrities were also converted to zoonyms, with some of them pertaining to emperors or kings (Akbar, Artemisia, Cezar, Cleopatra, Decebal, Flavian, Hannibal, King Arthur, Napoleon/Napoleone, Nero/Nerone; also fashionable a century ago, onymic units such as Cezar, Nero, Decebal and those echoeing personalities belonging to Turkish history were popular, such as Baiazid or Soliman. Other popular ones denoting prominent figures of the time included Hungarian ones - Banfi, Tisa, or German ones - Bismark, Pankop, Raap, Vilmoș 'Vilhelm II'). Names of presidents (Nixon), physicians (Galileo, Pascal), dominant social figures (Casanova, Fulvia, Rasputin), writers (Homer, Kabir, Kafka, Voltaire, Zola), painters (Miro, Monet, Rafael), singers or composers (Amadeus, Armin, Cher, Chopin, Elvis, Gaga, Keeno, Madonna, Rihanna, Shakira), actors (Clint Eastwood), magicians (Houdini), and football players (Hagi, Jong) were also trending at the time.

Charactonyms were not very common in the $20^{\text {th }}$ century, but they typically referenced mythological, biblical or legendary names (Daphne, Hector, Hipolita, Iossua, Iuda, Juno, Moneta, Novac, Ondina, Pintea, Uma, and Vesta). With respect to contemporaneity, literary characters (Dulcineea, Gretel, Harry Potter, Heidi, Hela, Hobbit, Iago, Othello, Peter Pan, Rogue, Superman, and Waldo), biblical names (Abel, Dalila, Goliat, Ismael, Nicanor, Ziba), deities from the Celtic, Greek, Roman, Egyptian or Norse mythology (Afrodita, Apollo, Ares, Artemis, Athena, Avenger, Belenus, Cupido/Cupidon, Damona, Demetra, Fortuna, Freja, Gaia, Hera, Hermes, Maat, Minerva, Odin, Poseidon, Thor, Zeus) were identified. Additionally, mythological or legendary characters (Aeneas, Andromeda, Atlas, Calipso, the lexical creation Calipsia, Dédalo Sp., Dionisio Sp., Elektra, Giunone It., Hector, Hercule, Isolde, Leda/Leta, 
Merlin/Merlino, Orfeo, Pandora, Parcifal, Tristano, Ulise, the lexical creation Ulisa), computer game characters (Alestera, Dellgado, Kintus, Lirhia, Orianna, Selius, Zavia, Zelda), movie characters (Ariel, Buffy, Darma, Elfo, The Flash, Jack Sparrow, Pippi, Quasimodo, Rambo, Rocky, Uberta, Zenigata, Zorro, Zuko) were also noted.

In 1922, the most common ethnonyms were the Romanian Cazacu 'Cassack', Neamțu 'German', Ovreiu 'Jewish', Rusu 'Russian', Tătaru 'Tartar', Țigan, Țiganca 'Gypsy'. Creating a skin colour analogy, contemporary zoonyms include Andaluz Rom. 'Andaluzian', Apache, Aztec, Dago 'a derogatory nickname referring to Italians and Spaniards', Gypsy, Hispánico Sp. 'Hispanic', Inca, Indio Sp. 'Indian', Indian Spirit, Kissi 'a West African ethnic group', Tiganu Rom. 'Gypsy', Zingaro It. 'Gypsy'. In addition, the names Sirio Sp. 'Syrian', Yankee and Zimba 'the name of a Bantu language' were also encountered at that time.

Whereas in 1922 the most common onymic units deriving from zoonyms were Ducipal or Elzorab, the 2019 trend included names of famous horses (Artax, Bucifal, Falada, Fluttershy, Pegas, Tornado), dogs (Laika, Lampo, Rolly, Snoopy, Togo, Varenne), deer (Bambi), elephants (Topsy), bears (Yogi), snakes (Hydra, Kaa), dinosaurs (Aladar), birds (Rom. Ciocănitoarea Woody / It. Picchiarello 'Woody Woodpecker') or cattle breeds (Angus).

Onyms coming from toponyms were quite rare in 1922 (Cichi<Hun. Csíki 'Ciuc', Cicsereda <Hun. Csíkszereda, Dulcea, Muşca, Plevna, Sedreș<Hung. Szedres, Volga). In 2019, a shift in the onomasticon occurred as it now includes names of continents (Antarctica, Asia), geographical regions (Antico Oriente, Hessa - in Germany, Lika in Croatia, Siberia, Zala - in Hungary), states/countries (Alabama, India, Indiana, Kentucky, Kenya, Libia, Nepal, Nicaragua, Ohio, Qatar), cities (in Romania: Constanța; in Europe: Atalaya, Athena, Chester, Fatima, Florence, Ginevra It. Geneva, Hannover, Tulla, Ursel, Windsor, York, Zahara; in North America: Arizona, Arkansas, Burbank, Colorado, Dakota, Las Vegas, Michigan, Nebraska, Oklahoma, Quebec, Texas, Wilbur; in South America: Havana; in Africa: Dakar, Nairobi; in Asia: Aira, Angora, Izumi, Kandy), villages (Lesmo - Italy), ancient cities (Cyrene, Melita, Morella, Petra, Pompei), neighbourhoods or districts (Cihangir, Lara, Manhattan, Triana), islands (Caraibe, Ibiza, Itaca, Marsela - also an anthroponym and a chrematonym, Wangi), oronyms (Athos - also a charactonym), volcanoes (Vesuvio), hydronyms (Danubio Sp. 'Danube', Niagara), fictional lands (Atlantis, Oz).

Other onymic units that transformed into zoonyms imply cosmonyms (Luna Rom. 'moon' - in both corpora, Pluto - in 1922, Antares, Lira, Lunar, Saturnia, Solar, Urania, Urano It., Venus; some units exhibit phenomena: Change of Moon, Eclipse/Eclisse It., Total Eclipse), chremathonyms (names of cars - Logan, Mini Cooper, Starlet, domestic appliances - Beko, Denon, Jocca, Vispa, tools - Wera, sports equipment - Nike, clothing companies - Chanel, hotel chains - Hilton, shops - Zara, sweets - Kit Kat, Raffaello, drinks - Albacher, Lord Campari, cigarette brands - Kent, drugs - Winstrol, swords Excalibur, ships - Argo, football clubs - Levante, software - Java, toys or games Barbie, Jack Flash, awards - Nobel). Names of months (July) and letters (Alfa, Kappa, Mega Omega) also feature among the new additions. Moreover, festivals (Woodstock), movies (Akira, Edera, Eragon, Viridiana, X-files), shows (Calimero), songs (Waka Waka), dances (in 1922, folk dances: Arva, Ciardaș, while in 2019, dances belonging 
to a more remote world: Bolero, Fandango, Tango), literary creations (Odissea), operas (Rigoletto, Tosca), zodiac signs (Taurus), and acronyms (Nafta - North American Free Trade Agreement, Nascar - National Association for Stock Car Auto Racing) are also new sources of onyms.

\section{CONCLUSIONS}

In a similar vein to the conclusions of our 2019 study, the contemporary Romanian lexicon of equine zoonyms exhibits a prolific and heterogeneous group. There are, however, discrepancies between the two centuries taken into consideration, which mirror the different historical contexts (due to the political changes, societal values and personal preferences) and the linguistic contact of nominators. In 1922, Hungarian, Russian and German were highly influential in producing new zoonyms. In 2019, English, Spanish, Italian and French were particularly dominant, with proper names of foreign origin being used even more pervasively than a century before (for example, names relying on the characteristic of beauty). This visibly manifested shift arises from multiculturalism and globalism. Interestingly, Latin is sometimes preferred nowadays due to its musicality or resonance alongside other foreign languages to the detriment of Romanian, since they are more exotic.

As far as the naming practices and patterns identified, it is self-evident that both transonymization and onymization occur. Additionally, there are less onomastic models that originate in the semantic field of colours, while strong and traditional names are no longer fashionable (for example, Murgu, Roibu); nevertheless, the reference to colours is still manifest at the imagery level, through associations related to animals, ethnic identity, natural phenomena, drinks, food or other objects. Moreover, the colour pattern sometimes carries a fantastic, non-realistic mark (Azure) and names are playfully adapted or adopted (Albastrro). As far as distinctive markings are concerned, most zoonyms from the past century have not stood the test of time, as these onymic units are not as common as they used to be.

The employment of more recent onomastic categories is also noteworthy, due to certain changes that occurred in the society. Nowadays, societal changes related a much wider spectrum of professions and a high appetite for entertainment have left a profound mark on the creation of new zoonyms.

Other onymic choices imply a more frequent use of proper names that rely on negative traits or they carry negative meaning in general (i.e., villains). Additionally, zoonym creation also draws from names suggesting ornaments and ostentation, names derived from nouns that designate human beings and social roles, or the more frequent employment of the superlative. Also, there is less employment of proper names deriving from appellatives that designate domestic animals - perhaps as a consequence of the fact that many people migrated from the rural to the urban spaces and their relationship with this reality changed. Derivatives of anthroponymic origin also saw fewer new onymic units. Besides, standard common zoonyms from a century ago that featured 'generic names' (Felecan 2014: 280-281) (Cezar, Bator, Bechiar, etc.) fell into disuse nowadays. 
Certain names still experienced continuity, sometimes at the level of the denotatum of the appellatives from which zoonyms originate (for example, animal or plant species, even if the proper names may occur in different languages), when it comes to the preference for certain ethnonyms (i.e., Gypsies, although nowadays exotic populations are also preferred), or to the predilection for foreign names, or to the occurrence of certain changes when words transit from one onymic class to another (derivation, cooccurrence of unusual words). Other examples of continuity refer to the appellatives transformed into proper names through which some temperament features are displayed, i.e. words that belong to the semantic sphere of animals or natural phenomena and which denote velocity and wilderness. Moreover, the referent can carry a positive or negative charge based on the chosen words and their implications, while some lexical units are neutral, especially when the initial semantic motivation is unknown.

Unlike our previous study, this paper is not the object of the owners' direct motivation regarding the choice of a certain name, because this kind of information was scarce. We could, however, suppose that motivations describe the animal or the owner, according to the way he/she perceives certain aspects related to the horse (Felecan 2014: 280-281), since the names reflect the owner's desires, perceptions or thoughts. Irrespective of the reasons behind the onomastic option, the attributed names contribute to developing and understanding the popular imaginary (Brâncuș 1967: 169).

\section{Sources}

A = www.uaterleft.ru/faq/2240-cele-mai-bune-nume-pentru-cai-\%C $\% \% 99$ i-iepe.html (accessed: 1.07.2020).

$\mathrm{B}=$ www.tarc.ro/blog/cele-mai-bune-nume-de-cai/ (accessed: 1.07.2020).

$\mathrm{C}=$ www.tpu.ro/conversatii/imi-spuneti-niste-nume-de-cai-funda-vot/ (accessed: 1.07. 2020).

$\mathrm{D}$ = rum.perhegrigh.ru/fermă/cai/10441-cum-de-a-alege-un-nume-pentru-cai. html (accessed: 1.07.2020).

$\mathrm{E}=$ animale.hosk.info/idei-nombres-caballos/ -un-nume-pentru-cai.html (accessed: 1.07.2020).

$\mathrm{F}=$ www.inlesa.ro/nume-de-cai-populare/ (accessed: 1.07.2020).

BIBLIOGRAPHY:

ANDREICA Anita, 2011, Relația dintre antroponime şi zoonime, (in:) Numele şi numirea. Actele ICONN 2011, Oliviu Felecan (ed.), Cluj-Napoca: Mega, 585-589.

Bran Răzvan, 2011, Zoonime grecești. Nume de câini în tratatul cinegetic al lui Xenophon, (in:) Numele şi numirea. Actele ICONN 2011, Oliviu Felecan (ed.), Cluj-Napoca: Mega, 597-603.

BRÂNCuș Gheorghe, 1967, Nume date animalelor domestice, LR XVI, 1: 169-175.

Felecan Daiana, 2014, Pragmatica numelui și a numirii neconvenționale: de la paradigme teoretice la practici discursive, Cluj-Napoca: Mega - Argonaut.

PAșCa Ștefan, 1936, Nume de persoane și nume de animale în Țara Oltului, București: Academia Română, Imprimeria Națională. 
Pop Sever, 1929, Câteva capitole din terminologia calului, Dacoromania V: 51-240.

PuşCAŞ Andreea-Nora, 2019, Nume de cai. Din răspunsurile la Chestionarul I, Dacoromania, serie nouă XXIV, 1: 20-41.

ZAFIU Rodica, 2006, Nume de animale, România literară 32, www.romlit.ro/index.pl/nume_de_animle (accessed: 22.06.2020). 